Acta Universitatis Wratislaviensis No 3799

DOI: $10.19195 / 0524-4544.324 .13$

\author{
ANDRZEJ PASEK \\ Uniwersytet Wrocławski \\ andrzej.pasek@uwr.edu.pl
}

\title{
Szkoły prawnicze jako przykład „demokratyzacji” wymiaru sprawiedliwości w początkach Polski Ludowej
}

Obóz komunistycznej lewicy, przejmujący władzę na ziemiach polskich u schyłku II wojny światowej, wprawdzie utrzymał co do zasady prawo obowiązujące w Rzeczypospolitej Polskiej w okresie międzywojennym, ale stopniowo wprowadzał do niego własne unormowania ${ }^{1}$. Stan prawny obowiązujący w Polsce do 1 września 1939 r. został przejęty także w zakresie organizacji wymiaru sprawiedliwości. Jednak do przepisów regulujących ustrój organów ochrony prawnej wprowadzano zmiany i uzupełnienia zmierzające do ich przekształcenia $\mathrm{w}$ dyspozycyjne narzędzie realizujące politykę aparatu władzy. W systemie politycznym tworzonym od połowy 1944 r., jeszcze pod szyldem „Polskiego Komitetu Wyzwolenia Narodowego", nie respektowano zasady niezawisłości sądownictwa. Nowe władze prowadziły „walkę o sądownictwo" nie tylko poprzez nowelizacje i uzupełnianie przepisów prawa materialnego i procesowego, ale także w sferze kadrowej ${ }^{2}$.

Ważne ustalenia dotyczące różnych aspektów kształtowania składu personalnego powojennego wymiaru sprawiedliwości zawierają opracowania Marcina Zaborskiego i Piotra Kładocznego ${ }^{3}$, problematyka ta poruszona została także w opracowaniach monograficznych Adama Lityńskiego i Anny Machnikowskiej ${ }^{4}$,

${ }^{1}$ A. Lityński, O prawie i sądach początków Polski Ludowej, Białystok 1999, s. 20.

2 Ibidem, s. 129-130.

${ }^{3}$ M. Zaborski, Szkolenie „sędziów nowego typu” w Polsce Ludowej, cz. 1. Średnie szkoty prawnicze, „Palestra” 1998, nr 1-2; M. Zaborski, Szkolenie „sędziów nowego typu” w Polsce Ludowej, cz. 2. Centralna Szkoła Prawnicza im. Teodora Duracza. Wyższa Szkoła Prawnicza im. Teodora Duracza, „Palestra” 1998, nr 3-4; P. Kładoczny, Kształcenie prawników w Polsce w latach 1944-1989, „Studia Iuridica” 35, 1998.

${ }^{4}$ A. Lityński, op. cit.; A. Machnikowska, Wymiar sprawiedliwości w Polsce w latach 19441950, Gdańsk 2008. 
incydentalnie obecna jest również w publikacjach innych autorów ${ }^{5}$. Niniejszy artykuł systematyzuje i uzupełnia wiedzę o powojennych szkołach prawniczych Ministerstwa Sprawiedliwości, nawiązując także do wcześniejszych zainteresowań autora $^{6}$. Natomiast pogłębionych badań wymaga dalszy przebieg kariery zawodowej absolwentów szkół prawniczych oraz Centralnej Szkoły Prawniczej i Wyższej Szkoły Prawniczej w Warszawie, a także kwestia ich umocowania prawnego w systemie wymiaru sprawiedliwości w zestawieniu z obowiązującym wówczas prawem.

Stanowiska w odtwarzanym stopniowo wymiarze sprawiedliwości obejmowały osoby zatrudnione uprzednio $\mathrm{w}$ analogicznych strukturach $\mathrm{w}$ okresie międzywojennym ${ }^{7}$. Jednak nowa władza nie ufała funkcjonariuszom przedwojennego wymiaru sprawiedliwości. Wpływowy wiceminister sprawiedliwości Leon Chajn zarzucał im „reakcyjność”, służbę w ramach ustawowych stanowiących zaprzeczenie ustroju „Polski Ludowej”, „negatywny stosunek do dokonanych w Polsce podstawowych przemian ustrojowych”, „wrogie nastawienie wobec ustroju demokratycznego" oraz oczekiwanie na "restytucję starego ustroju”" Tego rodzaju wypowiedzi w istocie przygotowywały grunt pod „demokratyzację" wymiaru sprawiedliwości. Na czym miał ten proces polegać, wyjaśniono w arty-

${ }^{5}$ A. Kozioł, Z prac Departamentu Szkolenia Zawodów Prawniczych i Popularyzacji Prawa w latach 1945-1950, [w:] Z dziejów prawa, cz. 3, red. A. Lityński, M. Mikołajczyk, W. Organiściak, Katowice 2002; A. Stawarska-Rippel, Prawnicy bez studiów, [w:] Z dziejów prawa...

${ }^{6}$ A. Pasek, Rekrutacja kandydatów do szkół prawniczych przez Polską Partię Robotniczą na terenie województwa wrocławskiego w latach 1946-1948, „Prawo” 264, Wrocław 1999.

7 „Ocenia się, że zgłosili się niemal wszyscy sędziowie i prokuratorzy, którzy przeżyli wojnę, a po wkroczeniu Armii Czerwonej i NKWD nie zostali wywiezieni w głąb ZSRR. [...] Ogółem w kraju zgłosiło się 37\% (prawie 1.300 z ogólnej liczby 3.500) przedwojennego stanu kadry sędziowskiej i prokuratorskiej, ale z uwagi na znaczny spadek liczby ludności oraz powojenną dezorganizację jeszcze pod koniec 1946 r. stanowili oni ogromną większość (około 90\%) sędziów i prokuratorów w służbie. Jeśli miały być zachowane pozory legalizmu — w okresie, kiedy władza komunistów nie była jeszcze utrwalona i kiedy sytuacja w Polsce mogła być przedmiotem zainteresowania mocarstw zachodnich — nie było powodów, by kadrze przedwojennej odmówić przyjęcia do służby" (A. Lityński, op. cit., s. 130).

8 ,Zarzuca się naszemu sądownictwu, że jest ono reakcyjne. Jeśli będziemy oceniali nasze sądownictwo według roli, jaką ono spełniało w Polsce do wrześniowej - to w imię prawdy przyznajemy, że na taką opinię ono zasłużyło” (L. Chajn, Sądy a prasa, „Demokratyczny Przegląd Prawniczy" (dalej jako: DPP) 1945, nr 1, s. 12).

9 „Nieufność polityczna wynika stąd, że obecny skład osobowy sądownictwa rekrutuje się przeważnie z pracowników przedwojennych. Dalecy jesteśmy od twierdzenia, że sądownictwo przedwojenne z całą świadomością polityczną wysługiwało się ówczesnemu reżymowi. Prawdą jest natomiast, że sądownictwo wykonywało swe funkcje w ramach ustawowych i na rzecz ustroju, będącego zaprzeczeniem ustroju obecnego. Usunięcie tej nieufności nastąpi, gdy będą stosowali nowe ustawy nie tylko formalnie, lecz gdy jednocześnie przełamią w sobie te opory i nawyki, które z natury rzeczy musiały w nich powstać w związku z długoletnim stosowaniem prawa w odmiennym ustroju społecznym” (L. Chajn, Teraźniejszość i przyszłość Polski Ludowej, Warszawa 1946, s. 27).

${ }^{10}$ L. Chajn, Trzeci rok, DPP 1946, nr 7, s. 7. 
kule opublikowanym w „Głosie Ludu” 24 października 1945 r. Organ prasowy Polskiej Partii Robotniczej pisał m.in.:

Dla zdemokratyzowania aparatu sądowego, dla zapewnienia społeczeństwu zgodnego z wymogami nowych czasów wymiaru sprawiedliwości, musi się otworzyć szeroko drzwi dla przedstawicieli mas robotniczych i chłopskich. Obok sędziów z wyższym wykształceniem prawniczym, obok tych sędziów i prokuratorów, którzy wykazali swą wierność i oddanie demokracji, należy dopuścić do rozstrzygania sporów, do ferowania wyroków w obronie praworządności, w obronie interesów państwa tych, których na stanowiska sędziowskie wysuną związki zawodowe i organizacje społeczne. Należy zorganizować skrócone, uproszczone przeszkolenie prawnicze dla tych ludzi, z których Minister Sprawiedliwości mógłby powoływać nowych sędziów ${ }^{11}$.

Był to postulat nie tylko zbieżny ze stanowiskiem Chajna, ale zapewne wręcz przez niego inspirowany, skoro tenże minister w swoich wystąpieniach żądał i ostrzegat:

Kto nie pójdzie z ludem, a przeciwko niemu — dla tego żadnych względów mieć nie będziemy. Możemy darować błędy przeszłości, ale od tego, kto chce iść z nami, pracować, żądamy całkowitego poddania się interesom demokracji. I to musi zrozumieć nasze sądownictwo, jeśli nie chce, aby obóz demokracji zmuszony był sięgnąć po nowe formy, bodaj kosztem zrezygnowania $\mathrm{z}$ kultu fachowości polskiego sądownictwa ${ }^{12}$.

Wyszkolenie nowych kadr dla wymiaru sprawiedliwości stało się zatem „,zagadnieniem pierwszorzędnej wagi" "13. W tym celu w Ministerstwie Sprawiedliwości utworzony został Departament Szkolenia Zawodów Prawniczych i Popularyzacji Prawa, który rozpoczął działalność w połowie października 1945 r. Departament ten powstał częściowo jako nowa jednostka organizacyjna, a częściowo przejął funkcje istniejącego wcześniej Biura Popularyzacji Prawa i samodzielnego referatu prasowego ${ }^{14}$.

W departamencie tym opracowano projekt zorganizowania kursów dla kandydatów na sędziów i prokuratorów niemających wykształcenia prawniczego, „celem dopuszczenia nowych, demokratycznych elementów do sądownictwa i prokuratury" 15 .

Gdy w okresie przedwojennym istniał nadmiar młodych sił prawniczych — argumentował dyrektor departamentu Jerzy Jodłowski — to w chwili obecnej stoimy wobec zjawiska braku tych sił. Na skutek tego wymiar sprawiedliwości zmuszony był oprzeć się w znakomitej większości na personelu sędziowskim i prokuratorskim przedwojennym, który nie zawsze stoi na wysokości nowych zadań, jakie zarysowały się przed sądownictwem. Wymiar sprawiedliwości jest jedynym bodaj resortem państwowym, którego zespół osobowy nie został odświeżony przez nowe siły wobec braku odpowiednio przeszkolonych kadr. Wyszkolenie tych nowych kadr staje się jednym z najpilniejszych zadań, stojących przed Ministerstwem Sprawiedliwości jako centralnym zarzą-

11 Demokratyzacja aparatu państwowego, „Głos Ludu” 1945, nr 282, s. 1.

${ }^{12}$ L. Chajn, Sady a prasa..., s. 13.

13 J. Jodłowski, Nowy Departament Ministerstwa Sprawiedliwości. Założenia — zadania struktura, DPP 1945, nr 2, s. 10.

${ }^{14}$ Ibidem.

15 Ibidem, s. 11. 
dem wymiaru sprawiedliwości. Zagadnienie to łączy się — nie ukrywał Jodłowski — z kwestią demokratyzacji sądownictwa, która jest postulatem coraz silniej wysuwanym przez różne sfery społeczeństwa i prasę [...]. Akcja szkoleniowa w tym zakresie, ze względu na swe znaczenie, wymagała jednolitego kierownictwa i spoczywać musiała w rękach Ministerstwa Sprawiedliwości ${ }^{16}$.

Plan nakreślony przez Jodłowskiego został - jak się okazało — zrealizowany w dekrecie z 22 stycznia 1946 r. o wyjątkowym dopuszczeniu do obejmowania stanowisk sędziowskich, prokuratorskich i notarialnych oraz do wpisywania na listę adwokatów (dekret styczniowy) ${ }^{17}$. W myśl art. 1 ust. 4 dekretu osoby, które ze względu na kwalifikacje osobiste oraz działalność naukową, zawodową, społeczną lub polityczną i dostateczną znajomość prawa nabytą bądź przez pracę zawodową, bądź w uznanych przez Ministra Sprawiedliwości szkołach prawniczych dawały rękojmię należytego wykonywania obowiązków sędziowskich lub prokuratorskich, mogły być mianowane na stanowiska asesora sądowego, sędziego lub prokuratora po udzieleniu im zwolnienia $\mathrm{z}$ wymogu ukończenia uniwersyteckich studiów prawniczych z przepisanymi w Polsce egzaminami, odbycia aplikacji sądowej i złożenia egzaminu sędziowskiego oraz przesłużenia określonej liczby lat na stanowiskach sędziowskich i prokuratorskich. Zwolnienia, zgodnie z art. 4, udzielić mógł Minister Sprawiedliwości w ciągu pięciu lat od dnia wejścia dekretu w życie ${ }^{18}$.

Dekret styczniowy wykorzystano do utworzenia szkół prawniczych, w których rozpoczęto ,akcję przeszkalania kadr sędziowskich i prokuratorskich spośród elementu obywatelskiego"19. Oznaczało to nie tylko radykalne zerwanie z lekceważonym nawet w oficjalnych wystąpieniach „kultem fachowości”, ale przede wszystkim z wymaganiami rozporządzenia Prezydenta Rzeczypospolitej z dnia 6 lutego 1928 r. Prawo o ustroju sądów powszechnych (dalej jako: Pr. o u.s.p.) ${ }^{20}$.

Zgodnie bowiem z art. 82 Pr. o u.s.p. na stanowisko sędziego mógł być mianowany ten, kto:

a) posiadał obywatelstwo polskie i korzystał z pełni praw cywilnych i obywatelskich,

b) był nieskazitelnego charakteru,

c) ukończył 25 lat,

d) władał językiem polskim w mowie i piśmie,

e) ukończył uniwersyteckie studia prawnicze z przepisanymi w Polsce egzaminami,

16 Ibidem, s. 10-11.

${ }^{17}$ Dekret z 22 stycznia 1946 r. o wyjątkowym dopuszczeniu do obejmowania stanowisk sędziowskich, prokuratorskich i notarialnych oraz do wpisywania na listę adwokatów (Dz.U. RP z 1946 r., Nr 4, poz. 33).

18 Dekret wszedł w życie w dniu 13 lutego 1946 r., jego moc prawna wygasła 13 lutego $1951 \mathrm{r}$.

19 Pierwsza szkoła prawnicza Ministerstwa Sprawiedliwości. Uroczyste otwarcie szkoły w Ło$d z i$, DPP 1946, nr 3-4, s. 86.

${ }^{20}$ Rozporządzenie Prezydenta Rzeczypospolitej z dnia 6 lutego 1928 r. Prawo o ustroju sądów powszechnych (t.j. Dz.U. RP z 1938 r., Nr 102, poz. 863). 
f) odbył aplikację sądową,

g) złożył egzamin sędziowski.

W myśl art. 83 Pr. o u.s.p. od wymagań, wymienionych w art. 82 ppkt f) i g), zwolnieni byli:

a) profesorowie i docenci nauk prawniczych na polskich uniwersytetach państwowych,

b) adwokaci i stali urzędnicy referendarscy Prokuratorii Generalnej Rzeczypospolitej Polskiej,

c) oficerowie korpusu sądowego, którzy byli sędziami, prokuratorami lub podprokuratorami wojskowymi.

Od kandydatów na sędziów, mających zająć stanowiska w sądach okręgowych, apelacyjnych lub w Sądzie Najwyższym, oprócz spełnienia warunków wymienionych w art. 82 i 83, przepis art. 85 Pr. o u.s.p. wymagał ponadto określonej liczby lat służby na stanowiskach sędziowskich lub prokuratorskich, a mianowicie:

a) od kandydatów na sędziów okręgowych — trzech lat służby na stanowisku przynajmniej sędziego grodzkiego, podprokuratora okręgowego lub trzyletniej po złożeniu egzaminu sędziowskiego służby na stanowisku sekretarza sądu okręgowego;

b) od kandydatów na prezesów i wiceprezesów sądów okręgowych oraz na wiceprezesów i sędziów apelacyjnych — trzech lat służby na stanowisku przynajmniej sędziego okręgowego lub wiceprokuratora okręgowego albo przynajmniej sześciu lat służby na stanowisku sędziego grodzkiego lub podprokuratora okręgowego — ogółem nie mniej niż sześć lat służby sędziowskiej lub prokuratorskiej;

c) od kandydatów na prezesów sądów apelacyjnych oraz na sędziów Sądu Najwyższego - trzech lat służby na stanowisku przynajmniej prezesa sądu okręgowego, sędziego apelacyjnego lub prokuratora apelacyjnego, prokuratora Sądu Najwyższego albo sześciu lat na stanowisku wiceprokuratora apelacyjnego lub co najmniej dziewięciu lat służby na stanowisku sędziego okręgowego lub wiceprokuratora okręgowego - ogółem najmniej dziewięciu lat służby sędziowskiej lub prokuratorskiej.

Przepis art. 85 Pr. o u.s.p. stanowił także, że Prezesem Sądu Najwyższego mógł zostać sędzia Sądu Najwyższego, pierwszy prokurator lub prokurator Sądu Najwyższego bądź prezes sądu apelacyjnego lub prokurator apelacyjny, o ile miał nie mniej niż 12 lat służby sędziowskiej lub prokuratorskiej.

Stosownie do art. 86 Pr. o u.s.p. postanowienia art. 85 znajdowały odpowiednie zastosowanie do sędziów i prokuratorów wojskowych, przy czym następujące stanowiska $\mathrm{w}$ sądownictwie wojskowym były równorzędne ze stanowiskami w sądach powszechnych:

a) sędziego w wojskowym sądzie rejonowym — z sędzią grodzkim,

b) podprokuratora przy wojskowym sądzie okręgowym $-\mathrm{z}$ wiceprokuratorem okręgowym, 
c) sędziego w wojskowym sądzie okręgowym i prokuratora przy tym sądzie — z sędzią okręgowym i prokuratorem okręgowym,

d) szefa wojskowego sądu okręgowego - z prezesem sądu okręgowego,

e) podprokuratora przy Najwyższym Sądzie Wojskowym — z prokuratorem Sądu Najwyższego,

f) wiceprezydenta i sędziego Najwyższego Sądu Wojskowego — z sędzią Sądu Najwyższego,

g) naczelnego prokuratora wojskowego — z pierwszym prokuratorem Sądu Najwyższego, a zastępcy naczelnego prokuratora i prokuratora przy Najwyższym Sądzie Wojskowym — z prokuratorem Sądu Najwyższego,

h) prezydenta Najwyższego Sądu Wojskowego — z prezesem Sądu Najwyższego.

W myśl art. 89 Pr. o u.s.p. sędzią Sądu Najwyższego mógł ponadto zostać:

a) profesor zwyczajny prawa na uniwersytecie państwowym polskim,

b) sędzia Najwyższego Trybunału Administracyjnego,

c) sędzia Najwyższego Sądu Wojskowego.

Na podstawie art. 90 Pr. o u.s.p. sędziów mianował Prezydent Rzeczypospolitej na wniosek Ministra Sprawiedliwości, przedstawiony w porozumieniu z Prezesem Rady Ministrów.

Na podstawie art. 236 Pr. o u.s.p. na stanowisko prokuratora mogła być mianowana osoba, która spełniła warunki określone w art. 82 i 83. Stosownie do art. 238 Pr. o u.s.p. podprokuratorów okręgowych mianował Minister Sprawiedliwości, a wszystkich innych prokuratorów - Prezydent Rzeczypospolitej na wniosek Ministra Sprawiedliwości, przedstawiony w porozumieniu z Prezesem Rady Ministrów.

W okresie międzywojennym prawników kształciły wyłącznie uniwersyteckie wydziały prawa. Realizowały one program ujęty w rozporządzeniu Ministra Wyznań Religijnych i Oświecenia Publicznego z dnia 16 października 1920 r. w sprawie organizacji studiów prawnych na uniwersytetach państwowych ${ }^{21}$. Rozporządzenie wskazywało minimalny wymiar godzin z przedmiotów obowiązkowych, który mógł zostać zwiększony uchwałą Rady Wydziału ${ }^{22}$. Studia na wszystkich wydziałach prawa uczelni państwowych miały trwać cztery lata, a każdy rok został podzielony na trzy trymestry. Na pierwszym roku studiów do przedmiotów obowiązkowych należały: prawo rzymskie, teoria prawa, historia prawa polskiego (ustroju i prawa sądowego) oraz historia prawa na zachodzie Europy. Na drugim roku studiów prawo kościelne, ekonomia polityczna (obejmująca teorię polityki, historię doktryn i politykę ekonomiczną), prawo polityczne (łącznie z nauką o państwie) oraz prawo

${ }^{21}$ Rozporządzenie Ministra Wyznań Religijnych i Oświecenia Publicznego z dnia 16 października 1920 r. w sprawie organizacji studiów prawnych na uniwersytetach państwowych (Dziennik Urzędowy Ministerstwa Wyznań Religijnych i Oświecenia Publicznego z 1920 r., Nr 22, poz. 140).

22 W. Wołodkiewicz, Nauczanie prawa czy przepisów prawnych, „Czasopismo Prawno-Historyczne" 68, 2015, z. 1, s. 237. 
narodów. Po dwóch latach studiów o charakterze historyczno-teoretycznym, od trzeciego roku student zapoznawał się z dogmatyką prawa w ramach zajęć ze skarbowości i prawa skarbowego, nauki administracji i prawa administracyjnego, statystyki, prawa karnego i postępowania karnego oraz filozofii prawa. Czwarty rok studiów obejmował nauczanie przedmiotów cywilistycznych: prawa cywilnego, postępowania sądowo-cywilnego, prawa handlowego i wekslowego oraz prawa międzynarodowego prywatnego. Ponadto każdy wydział mógł wprowadzać do programu studiów przedmioty fakultatywne, tj. socjologię, psychologię, logikę czy kryminologię $e^{23}$. Po złożeniu łącznie 17 egzaminów absolwenci otrzymywali dyplom i tytuł magistra praw. Po ukończeniu studiów prawniczych, kształcących bardziej prawnika-humanistę niż prawnika-praktyka, absolwenci mogli ubiegać się o przyjęcie na aplikację. Dopiero po zdaniu końcowych egzaminów aplikacyjnych, w tym także egzaminu sędziowskiego, mogli wykonywać zawody prawnicze ${ }^{24}$.

Program pierwszego powojennego roku studiów (1945/1946) nie różnił się w istotny sposób od poprzednio obowiązującego, z wyjątkiem uwzględnienia w nim rozporządzenia Ministra Wyznań Religijnych i Oświecenia Publicznego z dnia 12 sierpnia 1939 r. w sprawie organizacji studiów prawnych w szkołach akademickich ${ }^{25}$, ogłoszonego dopiero w $1945 \mathrm{r}^{26}$ Od $1946 \mathrm{r}$. inicjatywę w dyskusji nad nowym programem studiów prawniczych na uniwersytetach przejęło Ministerstwo Sprawiedliwości, a kontynuowano ją w kolejnych latach, ale równolegle w kręgach decyzyjnych tego resortu uważano, że uniwersytety nie wychowują młodzieży

w duchu demokratycznym, nie tworzą zatem demokratycznych kadr przyszłych sędziów i prokuratorów, ale - co gorsza - młodzież uniwersytecką pochodzenia robotniczego i chłopskiego w znacznej mierze wypaczają, wpływając na nią w duchu wstecznych teorii i poglądów ${ }^{27}$.

Natomiast duże nadzieje wiązano ze wspomnianymi wyżej szkołami prawniczymi.

${ }^{23}$ M. Marszał, Spór o model prawnika w Drugiej Rzeczypospolitej, „Krakowskie Studia z Historii Państwa i Prawa” 2015, nr 8 (2), s. 174-175.

24 P. Kładoczny, op. cit., s. 89.

25 Rozporządzenie Ministra Wyznań Religijnych i Oświecenia Publicznego z dnia 12 sierpnia 1939 r. w sprawie organizacji studiów prawnych w szkołach akademickich (Dziennik Urzędowy Ministerstwa Oświaty z 1945 r., Nr 8, poz. 333).

26 „Program ten obejmował następujące przedmioty: I rok - wstęp do nauk prawnych, prawo rzymskie, historia ustroju i prawa polskiego, historia prawa na zachodzie Europy, ekonomia polityczna; II rok - ekonomia polityczna (cd.), prawo państwowe, prawo narodów, prawo cywilne, prawo kościelne; III rok - prawo cywilne (cd.), prawo i postępowanie karne, skarbowość i prawo skarbowe, nauka administracji i prawo administracyjne; IV rok — nauka administracji i prawo administracyjne (cd.), prawo handlowe i wekslowe, postępowanie cywilne, prawo międzynarodowe prywatne, filozofia prawa. Poza wykładami obowiązkowymi każdy student musiał uczestniczyć w każdym roku akademickim w ćwiczeniach z co najmniej dwóch przedmiotów w wymiarze 2 godzin tygodniowo, czyli 120 godzin rocznie" (P. Kładoczny, op. cit., s. 90).

27 E. Merc, Szkoty prawnicze, DPP 1949, nr 3, s. 7. 
Powody uchwalenia dekretu z 22 stycznia 1946 r., który wykorzystano do utworzenia nowych szkół prawniczych, dobitnie wyłożył dyrektor Departamentu Szkolenia Zawodów Prawniczych i Popularyzacji Prawa Jerzy Jodłowski. W wystąpieniu z okazji rozpoczęcia działalności przez pierwszą tego rodzaju instytucję przekonywał on o konieczności

zdemokratyzowania sądownictwa i jak najszybszego wypełnienia luk, jakie powstały w sądownictwie na skutek długotrwałej wojny i okupacji. W chwili obecnej w sądownictwie polskim ponad 1000 etatów sędziowskich i prokuratorskich jest do obsadzenia, a świeży dopływ sił, które musiałyby przejść przez normalne studia i egzaminy nie może być prędko spodziewany ${ }^{28}$.

Urzędnik ten arbitralnie stwierdził, że

dzięki przepisom dekretu z 22 stycznia 1946 r. przełamana zostaje klanowość zawodów prawniczych, jaka cechowała je w Polsce przedwrześniowej i stworzona została możliwość awansu dla ludzi, dla których na skutek warunków społecznych i ekonomicznych dostęp do zawodów prawniczych był zamknięty ${ }^{29}$.

Pierwszą szkołę prawniczą Ministerstwa Sprawiedliwości utworzono już w marcu 1946 r. w Łodzi. W dniu 1 kwietnia 1946 r. rozpoczął się w niej pierwszy, planowany na sześć miesięcy, kurs dla kandydatów do prokuratury ${ }^{30}$. Kolejne takie szkoły otwarte zostały w krótkich odstępach czasu we Wrocławiu ${ }^{31}$, Gdańsku ${ }^{32}$, Toruniu $^{33}$, Szczecinie ${ }^{34}$ i Zabrzu ${ }^{35}$. Szkoły te funkcjonowały w latach $1946-1951^{36}$. Powoływano je bez odpowiedniej podstawy prawnej, albowiem za taką nie można przyjąć art. 1 ust. 4 dekretu. Mówił on o „uznanych przez Ministra Sprawiedliwości

28 Pierwsza szkoła prawnicza Ministerstwa Sprawiedliwości..., s. 87.

29 Ibidem.

30 J. Jodłowski, Akcja szkolenia kadr wymiaru sprawiedliwości, DPP 1946, nr 7, s. 33.

${ }^{31}$ Kronika, DPP 1947, nr 6, s. 60.

32 Kronika, DPP 1948, nr 3, s. 59.

33 Kronika, DPP 1948, nr 2, s. 58.

${ }^{34}$ Kronika, DPP 1950, nr 3, s. 63.

35 Ibidem.

${ }^{36}$ Szkoła w Łodzi działała do kwietnia 1952 r. Przeprowadzono w niej 6 kursów (3 prokuratorskie, 2 sędziowskie i 1 sędziowsko-prokuratorski), które ukończyło około 320 absolwentów. W czerwcu 1946 r. powstała szkoła prawnicza we Wrocławiu. Do końca 1953 r. przeprowadzono w niej 5 kursów (2 prokuratorskie, 2 sędziowsko-prokuratorskie i 1 sędziowski), które ukończyło łącznie 316 absolwentów. W szkole w Gdańsku w okresie grudzień 1947-wrzesień 1948 przeprowadzono 1 kurs prokuratorski, który ukończyło 66 absolwentów. Szkoła w Toruniu działała od kwietnia 1948 do kwietnia 1952 r. Przeprowadzono w niej 3 kursy (1 prokuratorski, 1 sędziowsko-prokuratorski i 1 sędziowski), które ukończyło około 190 absolwentów. W szkole prawniczej w Szczecinie, funkcjonującej od czerwca 1950 do sierpnia 1951 r., kurs sędziowski ukończyło około 150 absolwentów. W szkole w Zabrzu, istniejącej od czerwca 1950 do lipca 1951 r., zorganizowano 1 kurs prokuratorski, który ukończyło 92 absolwentów. Ogółem 6 szkół prawniczych ukończyło około 1130 absolwentów, spośród których 1081 podjęło pracę w wymiarze sprawiedliwości, w tym około 44\% w sądach, pozostali zaś w prokuraturach (Z. Ziemba, Przygotowanie i rozwój kadr sadownictwa Polski Ludowej, [w:] XXV lat wymiaru sprawiedliwości PRL, red. S. Jabłoński, Warszawa 1969, s. 145). 
szkołach prawniczych", nie zaś o tworzeniu przez ten organ takich szkół. Z kolei art. 2 ust. 2 ustawy z 11 marca 1932 r. o ustroju szkolnictwa stanowił, że organizację wszelkich typów szkolnictwa, z wyjątkiem przewidzianym w art. 51 ust. 2 tej ustawy, czas trwania nauki, programy oraz warunki przejścia z jednych szkół do drugich określa Minister Wyznań Religijnych i Oświecenia Publicznego. Programy przedmiotów zawodowych w szkołach zawodowych ustalał Minister Wyznań Religijnych i Oświecenia Publicznego po wysłuchaniu opinii ministrów zainteresowanych $\mathrm{w}$ zakresie ich ustawowo określonej właściwości ${ }^{37}$. Zgodnie $\mathrm{z}$ art. 51 ust. 2 owej ustawy o ustroju szkolnictwa organizację szkół akademickich określała osobna ustawa, ze zmianami wynikającymi z art. 52 i 53 ustawy o ustroju szkolnictwa. W myśl art. 1 ust. 2 owej „osobnej” ustawy z dnia 15 marca 1933 r. o szkołach akademickich założenie i likwidacja szkoły akademickiej oraz nadanie istniejącej już szkole praw szkoły akademickiej wymagało aktu ustawodawczego ${ }^{38}$.

Na podstawie art. 52 ustawy o ustroju szkolnictwa w szkołach wyższych studiować mogli absolwenci liceów ogólnokształcących, liceów dla wychowawczyń przedszkoli i liceów pedagogicznych oraz szkół zawodowych stopnia licealnego, którzy wykazali się świadectwem kwalifikującym do studiów w szkołach wyższych, jak też osoby, które uzyskały takie świadectwa na podstawie egzaminu. Nadto studiować mogły osoby, które nie odpowiadały powyższym warunkom, ale uzyskały zezwolenie Ministra Wyznań Religijnych i Oświecenia Publicznego na podstawie jednomyślnie przyjętego i przez Radę Wydziału umotywowanego wniosku. Tymczasem kandydaci do szkół prawniczych kierowani byli przez ,organizacje społeczne, partie polityczne i związki zawodowe" ${ }^{39}$. Indywidualne zgłoszenia nie były uwzględniane. Tłumaczono, że

przy dopuszczaniu elementu bez cenzusu wykształcenia stawia się wymóg, by brak ten wyrównany był wyrobieniem społecznym i walorami ujawnionymi w pracy społecznej. W ocenie, czy kandydat rzeczywiście te walory reprezentuje, orientować się będą najlepiej organizacje społeczne. One też muszą przyjmować na siebie odpowiedzialność za dobór kandydatów, jeśli idzie o ich oblicze społeczne czy polityczne, zwłaszcza, iż wchodzi tu w rachubę moment zaufania społecznego ${ }^{40}$.

Główną „organizacją społeczną”, która wyznaczała kandydatów, była Polska Partia Robotnicza (PPR), a poszukiwaniem ich zajmowały się wydziały personalne komitetów wojewódzkich, stosując się do poleceń Wydziału Personalnego Komitetu Centralnego PPR w Warszawie. Komitet wojewódzki zlecał z kolei komitetom powiatowym i miejskim (miast wydzielonych) PPR wskazanie 1-2 kandydatów spełniających następujące kryteria:

a) ukończone 23 lata,

37 Ustawa z 11 marca 1932 r. o ustroju szkolnictwa (Dz.U. RP z 1932 r., Nr 38, poz. 389).

38 Ustawa z dnia 15 marca 1933 r. o szkołach akademickich (t.j. Dz.U. RP z 1938 r., Nr 1, poz. 6).

39 J. Jodłowski, Akcja szkolenia kadr wymiaru sprawiedliwości..., s. 34.

40 Ibidem. 
b) wykształcenie przynajmniej w zakresie siedmioklasowej szkoły powszechnej,

c) zasadniczym warunkiem była przynależność do PPR, ale mogli być również bezpartyjni, lecz „uczciwi i bliscy ideowo”,

d) polityczna pewność - kandydat musiał być politycznie sprawdzony i mieć ,nienaganne oblicze moralne",

e) wyrobienie społeczne i polityczne, oczytanie oraz łatwość wypowiadania się w mowie i piśmie ${ }^{41}$.

Sekretarz komitetu powiatowego PPR zobowiązany był do przeprowadzenia indywidualnej rozmowy z każdą proponowaną osobą oraz zasięgnięcia o niej informacji we właściwym komitecie dzielnicowym, miejskim lub fabrycznym. Na tej podstawie rozstrzygał wstępnie, czy dany kandydat spełnia określone warunki. W przypadku uzyskania pozytywnej opinii, kandydat dostarczał komitetowi powiatowemu:

a) podanie o przyjęcie do szkoły prawniczej, zaadresowane do Departamentu Szkolenia Zawodów Prawniczych i Popularyzacji Prawa Ministerstwa Sprawiedliwości,

b) własnoręcznie napisany życiorys w dwóch egzemplarzach,

c) świadectwo ukończenia szkoły, jeśli takowe posiadał ${ }^{42}$.

Za wskazanie w wyznaczonym terminie odpowiednich kandydatów I sekretarz komitetu powiatowego lub miejskiego odpowiadał osobiście. Do dokumentów przygotowanych przez kandydata dołączał własną opinię lub charakterystykę. Następnie dokumenty przekazywał do wydziału personalnego komitetu wojewódzkiego PPR. Dalszego wyboru spośród zaproponowanych kandydatów dokonywano na szczeblu wojewódzkim. Kierownik wydziału personalnego komitetu wojewódzkiego wybierał spośród nich osoby w liczbie zbliżonej do limitu wyznaczonego przez Komitet Centralny przed rozpoczęciem każdego kursu. Wydział Personalny Komitetu Centralnego bardzo mocno akcentował obowiązek osobistej rozmowy kierownika wydziału personalnego Komitetu Wojewódzkiego z każdym kandydatem. Oczekiwano, że od jej wyników będzie zależała decyzja co do dalszych losów kandydata. Kierownik wydziału personalnego komitetu wojewódzkiego sporządzał ostateczną listę zaakceptowanych przez siebie osób i wraz z zebranymi dokumentami wysyłał do analogicznej komórki w Komitecie Centralnym. Przekazanie wytypowanych osób do dyspozycji Wydziału Personalnego Komitetu Centralnego kończyło partyjną procedurę rekrutacji kandydatów na przyszłych sędziów i prokuratorów. Następnie organ ten dostarczał zgromadzone podania właściwemu departamentowi Ministerstwa Sprawiedliwości. Stamtąd wysyłano zawiadomienia o terminie egzaminów wstępnych bądź bezpośrednio samym zainteresowanym, bądź do komitetu wojewódzkiego z prośbą o ich dalsze

\footnotetext{
${ }^{41}$ A. Pasek, op. cit., s. 259-260.

42 Ibidem.
} 
poinformowanie. W tym drugim wypadku komitet wojewódzki wydawał indywidualne skierowania. Ministerstwo Sprawiedliwości zastrzegało sobie prawo odrzucania podań poszczególnych kandydatów bez podania motywów ${ }^{43}$.

Zajęcia w szkołach prawniczych planowano początkowo na sześć miesięcy, następnie okres ten stopniowo w ramach kolejnych szkoleń wydłużano, maksymalnie do 15 miesięcy ${ }^{44}$. Pierwszy „kurs przeszkoleniowy” dla kandydatów do prokuratury, który rozpoczął się w kwietniu 1946 r. w Łodzi, trwał ostatecznie prawie osiem miesięcy. W dniach 1-4 kwietnia przeprowadzono egzamin wstępny, ustny i pisemny, którego celem była selekcja kandydatów na podstawie oceny ich inteligencji, orientacji i zasobu wiadomości ogólnych. Program kursu obejmował trzy grupy przedmiotów:

a) ogólne - ustrój państwa, ogólne zasady prawa, zasady wykładni prawa, ustrój gospodarczy Polski, zasady administracji i ustrój władz administracyjnych, zasady polityki społecznej i gospodarczej, ekonomię polityczną, ustrój sądów i prokuratury;

b) kryminologiczne - prawo karne materialne, postępowanie karne, prawo karne skarbowe, sądownictwo i postępowanie specjalne, kryminologię, politykę kryminalną, więziennictwo, biurowość i księgowość sądową i prokuratorską;

c) przedmioty pomocnicze - prawo cywilne, prawo handlowe, procedurę cywilną, zasady skarbowości.

Nauka w formie wykładów, seminariów, ćwiczeń oraz zajęć praktycznych trwała osiem godzin dziennie. Słuchaczy zakwaterowano w internacie oraz zapewniono im bezpłatne utrzymanie. Wykłady prowadzili przedstawiciele środowiska prawniczego, w tym Wydziału Prawno-Ekonomicznego Uniwersytetu Łódzkiego: Pierwszy Prokurator Sądu Najwyższego (SN) Piernikarski, sędziowie SN Jamontt, Potempa i Rappaport, prokuratorzy SN Siewierski i Gumiński, prokuratorzy sądu specjalnego Korytkowski i Lewiński, prokurator sądu okręgowego Kozłowski, prof. Batawia, prof. Wilamowski, prof. Namitkiewicz, doc. dr Ehrlich, adwokaci Jarosz, Litwin, Konopka, Gombiński, Mamrot i Zylbert ${ }^{45}$. Egzamin końcowy przeprowadzono w dniach 25-27 listopada 1946 r. Do egzaminu przystąpiło 48 uczestników zajęć, a w dniu 1 grudnia 1946 r. wręczono świadectwa ukończenia kursu 37 absolwentom ${ }^{46}$. Na podstawie tych pionierskich doświadczeń zorganizowano i przeprowadzono nie tylko następne edycje szkoleń w łódzkiej szkole prawniczej, ale także kursy w kolejno otwieranych tego rodzaju placówkach $^{47}$.

43 Ibidem, s. 260-262.

${ }^{44}$ M. Zaborski, Szkolenie „, sędziów nowego typu” w Polsce Ludowej, cz. 1, s. 87.

${ }^{45}$ Pierwsza szkoła prawnicza Ministerstwa Sprawiedliwości..., s. 86.

46 Zakończenie I-go kursu prokuratorskiego Szkoły Prawniczej w Lodzi. 37 nowych prokuratorów, DPP 1946, nr 11-12, s. 70.

${ }^{47}$ M. Zaborski, Szkolenie „sędziów nowego typu” w Polsce Ludowej, cz. 1, s. 84-87; P. Kładoczny, op. cit., s. 97-100. 
Dyrektor Departamentu Szkolenia Zawodów Prawniczych Jerzy Jodłowski przywiązywał dużą wagę do tej pierwszej szkoły prawniczej w zakresie „demokratyzacji” sądownictwa i prokuratury. Na podstawie pierwszych czterech miesięcy funkcjonowania tej szkoły stwierdził autorytatywnie, że była ona swoistym „poligonem doświadczalnym, terenem eksperymentalnym, pozwalającym wypróbować nowe metody nauczania prawa, właściwe drogi przygotowywania do zawodów prawniczych, właściwe metody i środki kwalifikacji i selekcji kandydatów i słuchaczy"48. Nie wszyscy zainteresowani jednak podzielali urzędowy entuzjazm Jodłowskiego. Sprawa ta stanowiła przedmiot ożywionej dyskusji jeszcze w trakcie X sesji Krajowej Rady Narodowej (KRN), obradującej w dniach 26-28 kwietnia 1946 r. Posłowie Polskiego Stronnictwa Ludowego zgłosili bowiem wniosek o uchwalenie przez KRN ustawy uchylającej dekret z 22 stycznia 1946 r., argumentując, że rezygnacja z wymogu cenzusu uniwersyteckiego może doprowadzić do obniżenia poziomu zawodowego i moralnego wśród pracowników wymiaru sprawiedliwości. Wniosek ten nie został jednak uwzględniony ${ }^{49}$. Niechętne było także stanowisko części środowiska prawniczego, co musiał przyznać nawet Jodłowski ${ }^{50}$. W przemówieniu z okazji zakończenia pierwszego kursu prokuratorskiego w Łodzi skarżył się on na „próby dyskryminacji ludzi, którzy z tej szkoły wyjdą [...], na walnym zjeździe Zrzeszenia Prawników Demokratów" oraz na „nieprzychylne wzmianki w prasie" ${ }^{51}$. Jednak ów niestrudzony promotor szkół prawniczych uznał głosy krytyki za przejaw klanowości cechującej środowisko prawników, obawiających się ,dopuszczenia do prokuratury i sądownictwa elementów demokratycznych”, którym ,sytuacja ekonomiczna nie pozwalała w okresie przedwojennym uzyskać dyplomu ukończonych studiów wyższych" ${ }^{52}$.

Obok istniejących już szkół prawniczych Ministerstwo Sprawiedliwości postanowiło założyć w maju 1948 r. Centralną Szkołę Prawniczą w Warszawie, $\mathrm{z}$ dwuletnim okresem nauki ${ }^{53}$. Okazało się bowiem, iż „akcja szkoleniowa” prowadzona w ramach już organizowanych kursów prawniczych nie rozwiązała problemu szybkiej „demokratyzacji” aparatu prokuratorsko-sądowniczego. Programy istniejących wcześniej szkół prawniczych ukierunkowane były na przygotowanie kandydatów na mniej odpowiedzialne stanowiska w sądownictwie i prokuraturze. Tymczasem Ministerstwo Sprawiedliwości „odczuwało brak ludzi o postawie zdecydowanie demokratycznej" także na stanowiskach kierowniczych. Z tych względów podjęto decyzję o utworzeniu szkoły prawniczej wyższego typu, która program uniwersytecki łączyłaby z umiejętnościami praktycznymi, jakie ofero-

48 J. Jodłowski, Akcja szkolenia kadr wymiaru sprawiedliwości..., s. 33.

${ }^{49}$ Zagadnienia Resortu Sprawiedliwości w obradach X sesji Krajowej Rady Narodowej, DPP 1946, nr 5-6, s. 51-53.

50 Zakończenie I-go kursu prokuratorskiego szkoły prawniczej w Łodzi..., s. 71.

${ }^{51}$ Ibidem.

52 Ibidem.

${ }^{53}$ Zob. P. Kładoczny, op. cit., s. 100-102. 
wała aplikacja sądowa. Z uwagi na program szkoły i oczekiwania pod adresem absolwentów od kandydatów wymagano spełniania następujących warunków:

a) wiek $21-40$ lat,

b) wykształcenie wyższe lub nieukończone wyższe, względnie średnie (matura),

c) całkowita gwarancja lojalnej pracy w służbie dla Polski Ludowej, wyrobienie polityczne i społeczne,

d) nienaganne oblicze moralne ${ }^{54}$.

Wobec dość wysokich wymagań stawianych kandydatom w pierwszym rzędzie „należało nastawiać się na towarzyszy”, którzy już rozpoczęli studia na Uniwersytecie, byłej Wolnej Wszechnicy czy dawnej Szkole Nauk Politycznych. Poza tym mogli być zgłoszeni kandydaci, którzy nie posiadali pełnej matury, ale stykali się z zagadnieniami prawniczymi $\mathrm{w}$ dotychczasowej pracy zawodowej, jak np. referenci w urzędach wojewódzkich, starostwach, instytucjach samorządowych. Przyjęcie do szkoły także w tym wypadku uzależnione było od wyniku egzaminu wstępnego, polegającego na sprawdzeniu stopnia rozwoju umysłowego, inteligencji, zasobu wiadomości ogólnych kandydata oraz znajomości języka polskiego w mowie i piśmie ${ }^{55}$.

Nowa szkoła została utworzona z dniem 1 czerwca 1948 r. na podstawie zarządzenia Ministra Sprawiedliwości z dnia 14 maja 1948 r. $^{56}$ Statut ${ }^{57}$ nadany 1 września 1948 r. wyznaczał jej dwa podstawowe zadania: kształcenie teoretyczne i praktyczne kandydatów na sędziów i prokuratorów oraz wychowywanie słuchaczy zgodnie z ideologią demokratyczną i sprawiedliwością społeczną ${ }^{58}$. Program dwuletnich zajęć, zwanych „studiami zawodowymi”, obejmował wykłady $\mathrm{z}$ podstawowych dziedzin prawa oraz rozbudowany blok doktryny marksistowskiej. Zadaniem tej szkoły było wykształcenie kadry kierowniczej dla instytucji wymiaru sprawiedliwości oraz podniesienie kwalifikacji przez absolwentów szkół prawniczych ${ }^{59}$. W dniu 1 kwietnia 1950 r. Centralna Szkoła Prawnicza otrzymała status szkoły wyższej ${ }^{60}$, tożsamy prawnie z pierwszym stopniem studiów uniwersyteckich, oraz nazwę Wyższej Szkoły Prawniczej im. Teodora Duracza. Nauka w tej Szkole kończyła się egzaminami dyplomowymi (równoważnymi egzaminowi sędziowskiemu), składanymi przed trzema komisjami, z zakresu:

54 A. Pasek, op. cit., s. 264-265.

55 Ibidem, s. 265-266.

56 Zarządzenie Ministra Sprawiedliwości z dnia 14 maja 1948 r. o utworzeniu Centralnej Szkoły Prawniczej im. Teodora Duracza (Dziennik Urzędowy Ministerstwa Sprawiedliwości z 1948 r., $\mathrm{Nr} 7$, brak nr pozycji).

${ }^{57}$ Statut Centralnej Szkoły Prawniczej im. Teodora Duracza (Dziennik Urzędowy Ministerstwa Sprawiedliwości z 1948 r., Nr 9, brak nr pozycji).

58 M. Zaborski, Szkolenie „sędziów nowego typu” w Polsce Ludowej, cz. 2, s. 105-106.

${ }^{59}$ A. Machnikowska, op. cit., s. 222.

${ }^{60}$ Rozporządzenie Rady Ministrów z 1 kwietnia 1950 r. w sprawie utworzenia Wyższej Szkoły Prawniczej im. Teodora Duracza (Dz.U. z 1950 r., Nr 13, poz. 126). 
a) materializmu dialektycznego i historycznego, historii Komunistycznej Partii Związku Radzieckiego i polskiego ruchu robotniczego,

b) prawa i procedury cywilnej,

c) prawa i procedury karnej.

Obok nielicznych profesorów innych uczelni akademickich stanowiska dydaktyczne obejmowali w niej przede wszystkim pracownicy Ministerstwa Sprawiedliwości, sądów, Prokuratury Generalnej i wyższych urzędów administracji państwowej. Wyższa Szkoła Prawnicza istniała do 31 sierpnia 1954 r., tj. do momentu przekształcenia jej w Centralny Ośrodek Doskonalenia Kadr Sędziowskich i Prokuratorskich ${ }^{61}$. Wyższa Szkoła Prawnicza i Centralna Szkoła Prawnicza wykształciły łącznie 421 absolwentów, w tym 83 absolwentów szkół prawniczych ${ }^{62}$.

Wprowadzenie w szerokim zakresie szczególnego trybu nominacji na stanowiska w wymiarze sprawiedliwości w początkach Polski Ludowej było konsekwencją braku zaufania nowej władzy do środowiska prawniczego II Rzeczypospolitej, czego nie ukrywano od początku tworzenia struktur władzy w Polsce Ludowej. Szkoły prawnicze powoływano, akcentując konieczność uzupełnienia braków kadrowych spowodowanych dużymi stratami osobowymi z lat wojny i okupacji, ale była to przede wszystkim próba szybkiego uzyskania decydującego wpływu na skład personalny wymiaru sprawiedliwości poprzez wprowadzenie do jego struktur ludzi nowych i lojalnych wobec nowej władzy politycznej.

\section{Bibliografia}

\section{Źródła}

Rozporządzenie Ministra Wyznań Religijnych i Oświecenia Publicznego z dnia 16 października 1920 r. w sprawie organizacji studiów prawnych na uniwersytetach państwowych (Dziennik Urzędowy Ministerstwa Wyznań Religijnych i Oświecenia Publicznego z 1920 r., Nr 22, poz. 140).

Rozporządzenie Prezydenta Rzeczypospolitej z dnia 6 lutego 1928 r. Prawo o ustroju sądów powszechnych (tekst jednolity Dz.U. RP z 1938 r., Nr 102, poz. 863).

Ustawa z dnia 11 marca 1932 r. o ustroju szkolnictwa (Dz.U. RP z 1932 r., Nr 38, poz. 389).

Ustawa z dnia 15 marca 1933 r. o szkołach akademickich (t.j. Dz.U. RP z 1938 r., Nr 1, poz. 6).

Rozporządzenie Ministra Wyznań Religijnych i Oświecenia Publicznego z dnia 12 sierpnia 1939 r. w sprawie organizacji studiów prawnych w szkołach akademickich (Dziennik Urzędowy Ministerstwa Oświaty z 1945 r., Nr 8, poz. 333).

Dekret z dnia 22 stycznia 1946 r. o wyjątkowym dopuszczeniu do obejmowania stanowisk sędziowskich, prokuratorskich i notarialnych oraz do wpisywania na listę adwokatów (Dz.U. RP z 1946 r., Nr 4, poz. 33).

${ }^{61}$ P. Kładoczny, op. cit., s. 101-102.

${ }^{62}$ Z. Ziemba, op. cit., s. 147. 
Statut Centralnej Szkoły Prawniczej im. Teodora Duracza (Dziennik Urzędowy Ministerstwa Sprawiedliwości z 1948 r., Nr 9, brak nr pozycji).

Zarządzenie Ministra Sprawiedliwości z dnia 14 maja 1948 r. o utworzeniu Centralnej Szkoły Prawniczej im. Teodora Duracza (Dziennik Urzędowy Ministerstwa Sprawiedliwości z 1948 r., $\mathrm{Nr} 7$, brak nr pozycji).

Rozporządzenie Rady Ministrów z dnia 1 kwietnia 1950 r. w sprawie utworzenia Wyższej Szkoły Prawniczej im. Teodora Duracza (Dz.U. z 1950 r., Nr 13, poz. 126).

\section{Literatura}

Chajn L., Sądy a prasa, „Demokratyczny Przegląd Prawniczy” 1945, nr 1.

Chajn L., Teraźniejszość i przyszłość Polski Ludowej, Warszawa 1946.

Chajn L., Trzeci rok, „Demokratyczny Przegląd Prawniczy” 1946, nr 7.

Demokratyzacja aparatu państwowego, „Głos Ludu” 1945, nr 282.

Jodłowski J., Akcja szkolenia kadr wymiaru sprawiedliwości, „Demokratyczny Przegląd Prawniczy" 1946, nr 7.

Jodłowski J., Nowy Departament Ministerstwa Sprawiedliwości. Założenia — zadania — struktura, „Demokratyczny Przegląd Prawniczy” 1945, nr 2.

Kładoczny P., Kształcenie prawników w Polsce w latach 1944-1989, „Studia Iuridica” 35, 1998.

Kozioł A., Z prac Departamentu Szkolenia Zawodów Prawniczych i Popularyzacji Prawa w latach 1945-1950, [w:], Z dziejów prawa, cz. 3, red. A. Lityński, M. Mikołajczyk, W. Organiściak, Katowice 2002.

Kronika, „Demokratyczny Przegląd Prawniczy” 1947, nr 6; 1948, nr 2 i 3; 1950, nr 3.

Lityński A., O prawie i sądach początków Polski Ludowej, Białystok 1999.

Machnikowska A., Wymiar sprawiedliwości w Polsce w latach 1944-1950, Gdańsk 2008.

Marszał M., Spór o model prawnika w Drugiej Rzeczypospolitej, „Krakowskie Studia z Historii Państwa i Prawa" 2015, nr 8 (2).

Merc E., Szkoły prawnicze, „Demokratyczny Przegląd Prawniczy” 1949, nr 3.

Pasek A., Rekrutacja kandydatów do szkót prawniczych przez Polska Partię Robotnicza na terenie województwa wrocławskiego w latach 1946-1948, „Prawo” 264, Wrocław 1999.

Pierwsza szkoła prawnicza Ministerstwa Sprawiedliwości. Uroczyste otwarcie szkoły w Łodzi, „Demokratyczny Przegląd Prawniczy" 1946, nr 3-4.

Stawarska-Rippel A., Prawnicy bez studiów, [w:] Z dziejów prawa, cz. 3, red. A. Lityński, M. Mikołajczyk, W. Organiściak, Katowice 2002.

Wołodkiewicz W., Nauczanie prawa czy przepisów prawnych, „Czasopismo Prawno-Historyczne” 68, 2015, z. 1.

Zaborski M., Szkolenie „sędziów nowego typu” w Polsce Ludowej, cz. 1. Średnie szkoty prawnicze, „Palestra” 1998, nr 1-2.

Zaborski M., Szkolenie „sędziów nowego typu” w Polsce Ludowej, cz. 2. Centralna Szkoła Prawnicza im. Teodora Duracza. Wyższa Szkoła Prawnicza im. Teodora Duracza, „Palestra” 1998, nr 3-4.

Zagadnienia Resortu Sprawiedliwości w obradach X sesji Krajowej Rady Narodowej, „Demokratyczny Przegląd Prawniczy" 1946, nr 5-6.

Zakończenie I-go kursu prokuratorskiego Szkoły Prawniczej w Łodzi. 37 nowych prokuratorów,

Ziemba Z., Przygotowanie i rozwój kadr sadownictwa Polski Ludowej, [w:] XXV lat wymiaru sprawiedliwości PRL, red. S. Jabłoński, Warszawa 1969. 


\title{
Law schools as an example of the "democratisation" of the justice system in the early days of the People's Republic of Poland
}

\begin{abstract}
Summary
The paper is devoted to the Ministry of Justice's law schools. The author presents the origins of the institutions as well as the special nature of the decree of 1946 on exceptional admissions to the office of judge, prosecutor and notary, and entry into the list of barristers and solicitors under the Court System Law of 1928. He discusses the functioning of law schools and their curricula. He demonstrates that the introduction of a special system of appointments to various offices in the justice system in the early days of the People's Republic of Poland stemmed from a lack of trust on the part of the new authorities in prosecutors and judges of the Second Polish Republic. Consequently, using staff shortages caused by the war and occupation as an excuse, the government decided to try to gain decisive influence on the justice system by appointing graduates of the law schools as judges and prosecutors, in return expecting loyalty to the new political authorities.
\end{abstract}

Keywords: law school, judge, prosecutor, training, judiciary

\section{Die Rechtsschulen als Beispiel der „Demokratisierung“ der Rechtspflege am Anfang der Volksrepublik Polen}

\section{Zusammenfassung}

Die Bearbeitung wurde den Rechtsschulen des Justizministeriums gewidmet. Präsentiert wurde die Genese der Institution und der besondere Charakter des Dekretes von 1946 über die Sonderzulassung zur Übernahme der Posten als Richter, Staatsanwalt und Notar und zur Eintragung in die Liste der Rechtsanwälte vor dem Hintergrund des Rechts über das System der ordentlichen Gerichte aus dem Jahre 1928. Besprochen wurden die Tätigkeit der Rechtsschulen und ihre Lehrprogramme. Es wurde bewiesen, dass der Sondermodus der Berufung in die Posten im Justizwesen in den Anfängen der Volksrepublik Polen sich aus dem fehlenden Vertrauen der neuen Macht zu den Staatsanwälten und Richtern der Zweiten Polnischen Republik ergab. Infolgedessen, unter dem Vorwand, den Kadermangel zu beseitigen, der durch den Krieg und die Besatzungszeit verursacht wurde, wurde versucht, entscheidenden Einfluss auf die personelle Besetzung der Postem im Justizwesen zu nehmen, indem die richterlichen und staatsanwaltlichen Posten mit Absolventen der Rechtsschulen besetzt wurden. Als Gegendienst erwartete man von ihnen die Loyalität der neuen Macht gegenüber.

Schlüsselworte: Rechtsschule, Richter, Staatsanwalt, Schulung, Gerichtswesen 